\title{
EFISIENSI PRODUKSI USAHA SAPI PERAH RAKYAT (STUDI KASUS PADA PETERNAK ANGGOTA KOPERASI USAHA PETERNAKAN DAN PEMERAHAN SAPI PERAH KALIURANG, SLEMAN, YOGYAKARTA)
}

\section{PRODUCTION EFFICIENCY OF SMALLHOLDER DAIRY CATTLE FARMING (CASE STUDY ON THE FARMER MEMBERS OF DAIRY CATTLE FARM OF KALIURANG COOPERATIVE, SLEMAN, YOGYAKARTA)}

\author{
Melani Astuti*, Rini Widiati, dan Yustina Yuni Suranindyah \\ Fakultas Peternakan, Universitas Gadjah Mada, Jl. Fauna No.3, Bulaksumur, Yogyakarta, 55281
}

\section{INTISARI}

Penelitian ini bertujuan untuk mengetahui rasionalitas dan efisiensi alokatif usaha sapi perah rakyat dalam menggunakan faktor produksi, dilakukan mulai bulan Juni sampai dengan Agustus 2009 di wilayah Koperasi Usaha Peternakan dan Pemerahan Sapi Perah (UPP) Kaliurang, Kabupaten Sleman. Sampel peternak diambil secara purposive sampling sejumlah 40 responden. Pengambilan data dengan metode survei menggunakan kuesioner untuk mengumpulkan data primer dari responden dan data sekunder dari dinas terkait. Untuk mengetahui faktor produksi yang berpengaruh terhadap produksi susu digunakan fungsi regresi model Cobb-Douglas dengan unit analisis per peternak. Estimasi koefisien regresi dengan metode OLS, selanjutnya dilakukan uji efisiensi alokatif. Hasil analisis menunjukkan bahwa pakan hijauan, konsentrat, luas pemilikan lahan hijauan, tenaga kerja, jumlah ternak dan persentase induk laktasi secara bersama-sama berpengaruh signifikan terhadap produksi susu dengan $\mathrm{R}^{2}=0,78$. Secara parsial persentase induk laktasi dan jumlah ternak berpengaruh signifikan positif $(\mathrm{P}<0,01$ dan $\mathrm{P}<0,1)$ terhadap produksi susu per peternak, namun jumlah pakan hijauan dan konsentrat tidak berpengaruh signifikan. Hal ini didukung hasil uji efisiensi alokatif juga menunjukkan bahwa penggunaan pakan hijauan dan konsentrat belum mencapai efisiensi alokatif. Secara teknis penggunaan faktor produksi belum rasional ditunjukkan dengan elastisitas produksi (Ep) >1 (1,462).

(Kata kunci: Efisiensi produksi usaha, Sapi perah rakyat, Faktor-faktor produksi)

\section{ABSTRACT}

The objective of the study was to investigate rationality and allocative efficiency of the utilisation of production factors in smallholder dairy farmers. The study was conducted from June to August 2009 in the region of UPP Kaliurang cooperative, Sleman, Yogyakarta. There were forty respondents of smallholder dairy farmers taken by purposive sampling method. The primary data were taken from respondents and secondary data were from related institutions. Regression function of Cobb-Douglass model was used to determine the production factor which influenced milk production. Data were analysed based on unit/farmer. Coefficient of regression was estimated with Ordinary Least Square (OLS), further analysis was conducted by allocative efficiency. The result of this study showed that forage, concentrate, land owned/farmer, labor, number of livestock and percentage of lactating cows significantly affected the milk production $\left(R^{2}=0.78\right)$. Partially, percentage of lactating cows and total dairy cows had positive effect $(P<0.01$ and $P<0.1)$ on the milk production of each farmer, however forage and concentrates did not affect the milk production. The result of allocative efficiency test showed that input consisted of forage and concentrates in this study have not achieved efficienly. Technically, the utilisation of production factors had not been rational, it was shown by the production elasticity $\left(E_{p}\right)>1$ (1.462).

(Key words: Production of efficiency, Smallholder dairy farming, Factors of production)

\section{Pendahuluan}

Populasi sapi perah di Indonesia pada periode tahun 2003 sampai dengan 2007 meningkat dari 374.000 ekor menjadi 378.000 ekor. Kenaikan po-

\footnotetext{
* Korespondensi (corresponding author):

Telp. +6281329703455

E-mail: melani109@yahoo.com
}

pulasi sapi perah secara rata-rata per tahun adalah 0,2\%. Ditinjau dari konsumsi susu pada tahun 2003 adalah $6,5 \mathrm{~kg} / \mathrm{kapita} / \mathrm{tahun}$ dan tahun 2007 adalah $11 \mathrm{~kg} / \mathrm{kapita} / \mathrm{tahun}$, kenaikan rata-rata per tahun adalah 8,2\% (Ditjen Peternakan, 2008). Berdasarkan data tersebut dapat diketahui bahwa tingkat kenaikan produksi sapi perah lebih kecil dari pada tingkat kenaikan konsumsi susu. Lambatnya peningkatan produksi susu karena sebagian besar atau 
lebih dari $90 \%$ usaha sapi perah merupakan peternakan rakyat dengan skala kecil dengan pemeliharaan secara tradisional, dan diduga belum efisien sehingga produksi dan produktivitas rendah. Sejak usaha sapi perah berkembang di Indonesia pada tahun 1979, sampai sekarang ciri-cirinya tidak banyak berubah, sapi perah diusahakan oleh peternakan rakyat berbasis usaha keluarga dengan skala usaha kecil-kecil (1-4 ekor sapi per peternak). Kondisi tersebut menggambarkan bahwa peternak dihadapkan pada keterbatasan faktor produksi, manajemen, dan teknologi pemeliharaannya juga sederhana.

Ditinjau dari sisi peternak tujuan usaha ternak sapi perah adalah mendapatkan keuntungan dari susu, pedet, dan pupuk kandang. Dalam melakukan proses produksi perlu sarana faktor produksi, berupa modal, lahan, dan tenaga kerja. Sementara pada peternakan rakyat pemilikan faktor produksi tersebut rendah atau sangat terbatas, sehingga untuk memaksimalkan keuntungan perlu alokasi faktor produksi secara efisien dan optimal.

Dalam proses produksi suatu barang/jasa, termasuk proses produksi sapi perah, keuntungan akan dipengaruhi oleh biaya penggunaan sumber daya dan manajemen usaha. Secara teori ekonomi proses produksi dapat digambarkan sebagai fungsi produksi yang merupakan hubungan antara produk dan penggunaan faktor produksi atau sumber daya. Melalui fungsi produksi dapat dipelajari efisiensi penggunaan faktor tersebut. Efisiensi ekonomi terdiri dari efisiensi teknis dan harga. Menurut Yotopoulus dan Nugent (1976), efisiensi teknis adalah kemampuan untuk memperoleh output yang maksimum melalui penggunaan suatu tingkat input atau sumberdaya tertentu. Menurut Soekartawi (1990), efisiensi harga atau efisiensi alokatif diartikan sebagai suatu kondisi nilai produk marjinal (NPM) untuk suatu input sama dengan harga input tersebut. Efisiensi teknis dan efisien harga akan memberikan petunjuk bagi petani untuk mengalokasikan sumber daya atau faktor produksi yang memaksimumkan keuntungan. Mempelajari efisiensi pada proses produksi peternakan sapi perah rakyat adalah penting karena peternak dihadapkan pada keterbatasan-keterbatasan sumberdaya atau faktor produksi.

Berdasarkan latar belakang di atas, peneliti tertarik untuk mengetahui bagaimana kondisi produksi sapi perah rakyat dengan mengambil studi kasus pada peternak anggota Koperasi Usaha Peternakan dan Pemerahan Sapi Perah (UPP) Kaliurang, Sleman, Daerah Istimewa Yogyakarta.

Tujuan penelitian ini adalah menentukan faktor-faktor produksi yang berpengaruh signifikan terhadap produksi susu sapi perah rakyat, mengetahui rasionalitas penggunaan faktor-faktor produksi pada usaha sapi perah rakyat, dan menentukan efisiensi alokatif penggunaan faktor produksi.

\section{Materi dan Metode}

\section{Lokasi dan waktu penelitian}

Lokasi penelitian adalah wilayah Koperasi Usaha Peternakan dan Pemerahan Sapi Perah (UPP) Kaliurang Sleman, dan peternak sapi perah sebagai anggota koperasi. Penelitian dilaksanakan pada bulan Juni sampai Agustus 2009.

\section{Materi}

Materi dalam penelitian ini adalah peternak sapi perah. Responden diambil dari para anggota koperasi UPP Kaliurang Sleman yang memiliki minimal 1 ekor ternak sapi perah yang sedang laktasi.

\section{Metode}

Metode penelitian adalah metode survei dengan sampel peternak atau responden yang ditetapkan secara purposive sampling sebesar 40 peternak responden, berdasarkan jumlah pemilikan sapi perah laktasi minimal 1 ekor, dan sudah memelihara minimal 1 tahun sapi perah. Menurut Hadi (2000), purposive artinya pengambilan sampel sesuai dengan tujuan penelitian yang telah ditetapkan. Pengambilan sampel peternak (responden) secara convinience didasarkan pada informasi dari pengurus koperasi/kelompok. Menurut Hadi (2000), convinience sampling maksudnya mengambil sampel yang sesuai dengan ketentuan atau persyaratan sampel dari populasi tertentu yang paling mudah dijangkau atau didapatkan.

\section{Analisis data}

Data yang diperoleh kemudian ditabulasi, dianalisis dan dilakukan interpretasi data dengan unit analisis per peternak. Transformasi persamaan regresi berganda fungsi Cobb-Douglas menjadi fungsi produksi linier dengan mentransfer menjadi log atau ln. Fungsi produksi Cobb-Douglas digunakan untuk menguji hipotesis pertama dan kedua. Model fungsi tersebut seperti persamaan berikut:

\section{Keterangan}

$$
\mathrm{Yt}=\mathrm{A}_{1} \mathrm{X}_{1}^{\mathrm{b} 1} \mathrm{X}_{2}^{\mathrm{b} 2} \mathrm{X}_{3}^{\mathrm{b} 3} \ldots \mathrm{Xn}^{\mathrm{b} 6} \mathrm{e}^{\mu}
$$

Yt : Produksi susu (liter/hari/peternak)

A : Intersep

$\mathrm{X}_{1} \quad$ : Pakan hijauan (kg/hari/peternak)

$\mathrm{X}_{2} \quad$ : Pakan konsentrat (kg/hari/peternak)

$\mathrm{X}_{3} \quad$ : Luas lahan hijauan $\left(\mathrm{m}^{2}\right)$

$\mathrm{X}_{4} \quad$ : Tenaga kerja (HOK/peternak)

$\mathrm{X}_{5} \quad$ : Jumlah ternak (UT)

$\mathrm{X}_{6} \quad$ : Persentase induk laktasi terhadap total ternak $(\%)$

$\mu \quad$ : variabel gangguan (disturbance term) 
$b_{1} \ldots b_{6}$ : koefisien regresi

Mengingat fungsi produksi tersebut non linier, maka perlu dilakukan tranformasi dobel log yaitu $\ln =$ logaritma natural dengan basis $\mathrm{e}=2,718$.

\section{Uji hipotesis I}

$$
\mathrm{L}_{\mathrm{n}} \mathrm{Yt}=\mathrm{L}_{\mathrm{n}} \mathrm{A}+\mathrm{b}_{1} \mathrm{~L}_{\mathrm{n}} \mathrm{X}_{1}+\mathrm{b}_{2} \mathrm{~L}_{\mathrm{n}} \mathrm{X}_{2}+\ldots \mathrm{b}_{6} \mathrm{~L}_{\mathrm{n}} \mathrm{X}_{6}+\mu
$$

$\mathrm{H} 0: \mathrm{b}_{1} \ldots \mathrm{b}_{\mathrm{n}}=0$

Ha: $b_{1} \ldots b_{n} \neq 0$

Dimana $\alpha=\ln \mathrm{A}$, model ini linear dalam parameter $\alpha$ dan $\mathrm{b} 1$ dan linear dalam logaritma $\mathrm{Y}$ dan $\mathrm{X}$, jadi disebut model log-ganda.

Untuk menguji signifikansi model dilakukan uji $\mathrm{F}$ pada semua faktor produksi secara bersamasama $\left(\mathrm{X}_{1} . . \mathrm{Xn}\right)$ terhadap $\mathrm{Y}$ (produksi susu). Untuk menetapkan nyata tidaknya pengaruh masingmasing faktor produksi yang dimasukkan ke dalam model terhadap produksi susu dilakukan uji $\mathrm{t}$ (Gujarati, 2003).

Koefisien Determinasi $\left(\mathrm{R}^{2}\right)$ adalah koefisien determinasi yang menyatakan besarnya pengaruh faktor produksi terhadap produksinya (Gujarati, 2003).

\section{Uji hipotesis II}

Dalam fungsi produksi Cobb-Douglas $\mathrm{b}=$ elastisitas produksi (Ep) selanjutnya hipotesisnya adalah:

Ho : Apabila Ep $>1$ dan Ep $<0$, maka peternak sapi perah rakyat tidak rasional secara teknis dalam menggunakan faktor produksi.

Ha : Apabila elastisitas produksi pada daerah $0<$ Ep $<1$, maka peternak sapi perah rakyat rasional secara teknis dalam menggunakan faktor produksi.

Elastisitas produksi (Ep) adalah penjumlahan dari $b_{1}$ $+b_{2}+\ldots+b_{6}$.

\section{Uji hipotesis III}

Efisiensi alokatif penggunaan masing-masing faktor produksi dapat dilihat nilai MVPx (Nilai hasil produk marginal) masing-masing faktor produksi terhadap Pxi (harga masing-masing faktor produksi) atau sering disebut nilai $\mathrm{k}$.

Ho : $\mathrm{k}_{\mathrm{i}}=1$, penggunaan input ke-i sudah efisien secara alokatif (harga).
Ha $: \mathrm{k}_{\mathrm{i}} \neq 1$, penggunaan input ke-i belum/tidak efisien alokatif (harga).

\section{Hasil dan Pembahasan}

\section{Profil Koperasi Usaha Peternakan dan Pemerahan Sapi Perah (UPP) Kaliurang Sleman}

\section{Keadaan geografi}

Koperasi Usaha Peternakan dan Pemerahan Sapi Perah (UPP) Kaliurang berlokasi di daerah lereng gunung Merapi bagian selatan. Wilayah kerja Koperasi UPP Kaliurang termasuk daerah perbukitan yang meliputi lima desa dan tiga kecamatan di wilayah Kabupaten Sleman.' Wilayah kerja koperasi UPP Kaliurang dibatasi oleh dua kelurahan wilayah Kecamatan Pakem, dua kelurahan wilayah Kecamatan Cangkringan, satu kelurahan wilayah Kecamatan Turi. Tinggi tempat rata-rata $900 \mathrm{~m}$ dari permukaan laut, suhu udara $20-25^{\circ} \mathrm{C}$ dan curah hujan rata-rata $2230 \mathrm{~mm}$ per tahun. Suhu udara tersebut sangat sesuai untuk kehidupan sapi perah (Soetarno, 2000).

\section{Identitas peternak}

Karakteristik peternak yang diamati dalam penelitian ini meliputi tingkatan umur, pendidikan formal, pengalaman beternak, mata pencahariaan, dan tanggungan keluarga, secara lengkap tersaji pada Tabel 1.

Pengelolaan usaha sapi perah rakyat ditentukan oleh manajemen pengelolanya yaitu peternak. Untuk mengetahui gambaran tentang karakteristik peternak perlu diketahui informasi tentang latar belakang peternak yang berhubungan usaha pemeliharaan sapi perah rakyat.

\section{Produksi susu}

Produksi susu sapi perah terutama dipengaruhi oleh bulan laktasi dan umur sapi. Besarnya atau jumlah susu yang dihasilkan peternak per rumah tangga (RT) tergantung pada jumlah induk laktasi dan manajemen usahanya. Rata-rata produksi susu per peternak, jumlah induk laktasi, dan ratarata bulan laktasi sapi perah yang dipelihara oleh peternak responden seperti tersaji pada Tabel 2.

Tabel 1. Karakteristik peternak sapi perah responden anggota koperasi usaha peternakan dan pemerahan sapi perah Kaliurang, Sleman, Yogyakarta (characteristics of respondents of dairy cow farmers, member dairy cattle of Kaliurang cooperative, Sleman, Yogyakarta)

\begin{tabular}{lcc}
\hline \hline \multicolumn{1}{c}{ Uraian (variable) } & Kisaran (range) & Rata-rata (average) \\
\hline Umur (tahun) (age (year)) & $30-76$ & $50,83 \pm 10,87$ \\
Lama pendidikan (tahun) (length of study (years)) & $0-12$ & $5,8 \pm 3,39$ \\
Pengalaman (tahun) (experience (years)) & $1-40$ & $18,2 \pm 9,85$ \\
Jumlah anggota keluarga (orang) (number of family member (people)) & $2-6$ & $3,6 \pm 1,25$ \\
\hline
\end{tabular}


Tabel 2. Rata-rata produksi susu, bulan laktasi dan jumlah pemilikan sapi perah peternak anggota koperasi usaha peternakan dan pemerahan sapi perah Kaliurang, Sleman, Yogyakarta (averages of milk production, lactating months, and number of dairy cattle of farmers, member dairy cattle of Kaliurang cooperative, Sleman, Yogyakarta)

\begin{tabular}{lcc}
\hline \hline \multicolumn{1}{c}{ Uraian (variables) } & Rata-rata (average) & Kisaran (range) \\
\hline $\begin{array}{l}\text { Produksi susu (1/hr/responden) (milk production (l/day/respondent)) } \\
\text { Jumlah Induk laktasi (UT) (number of lactating cows (AT)) }\end{array}$ & $20,03 \pm 12,83$ & $6-49,18$ \\
$\begin{array}{l}\text { Rata-rata produksi susu/induk laktasi (1/UT/hr) (average of milk } \\
\text { production/lactating cows (l/AT/day)) }\end{array}$ & $8,30 \pm 1,62$ & $1-6$ \\
$\begin{array}{l}\text { Bulan laktasi (bulan ke-) (lactating months) (months)) } \\
\text { Jumlah ternak (UT) (number of dairy cattle (AU)) }\end{array}$ & $4,92-17,21$ \\
$\begin{array}{l}\text { Persentase jumlah induk laktasi/total ternak (\%) (number of lactating } \\
\text { cows/number of dairy cattle (\%)) }\end{array}$ & $3,63,70 \pm 2,50 \pm 16,70$ & $1-10$ \\
\hline
\end{tabular}

Pada Tabel 2, produksi susu per induk laktasi pada peternak responden masih rendah, dengan rata-rata per peternak $21,51 /$ hari dan rata-rata produksi per induk laktasi ternak 9,69 1/hari pada rata-rata bulan laktasi ke 4,67 bulan. Menurut Yusdja (2005), produksi susu pada peternak dalam memelihara sapi perah pada umumnya di bawah 10 liter per hari, sekalipun menggunakan bibit sapi perah unggul yang sebenarnya mampu berproduksi 15-20 liter per hari. Induk laktasi yang dimiliki peternak responden rata-rata 2,3 unit ternak yang berarti indikator ini menunjukkan belum efisien. Dengan rata-rata pemilikan sapi sebanyak 3-5 ekor peternak, tingkat efisiensinya masih rendah. Persentase jumlah induk laktasi per total ternak sekitar $63,7 \%$, yang berarti persentase jumlah induk laktasi per total ternak belum dapat mempengaruhi produksi susu sapi perah. Menurut Winarno (1985), persentase induk laktasi dapat berpengaruh terhadap produksi susu bila persentasenya lebih dari $80 \%$.

Pemberian pakan konsentrat rata-rata per UT adalah 6,5 kg/hari dan produksi susu 9,69 1/hr. Menurut Siregar (2000), pakan yang dibutuhkan tergantung pada bobot badan sapi perah dan susu yang dihasilkan. Hasil penelitian Purwanto (1983) cit. Zakaria (1986) menunjukkan bahwa rata-rata pemberian hijauan/satuan ternak (ST)/hari di daerah Pujon berkisar antara 33,77-44,34 kg dan rata-rata pemberian pakan penguat/ST/hari berkisar antara 6,54-7,87 kg. Dari hasil penelitian di Koperasi UPP Kaliurang, Sleman, pakan hijauan berkisar antara $28,85-62,5 \mathrm{~kg} / \mathrm{UT} /$ hari dengan rata-rata $25,9 \mathrm{~kg} / \mathrm{ST}$, dan konsentrat 4,57-8,85 kg/UT/ hari dengan ratarata $6,5 \mathrm{~kg} / \mathrm{UT} / \mathrm{hari}$.

\section{Sarana produksi usaha sapi perah}

Tabel 3 menunjukkan bahwa rata-rata pemberian pakan hijauan dan konsentrat adalah 42,9 dan $6,5 \mathrm{~kg} / \mathrm{UT} / \mathrm{hari}$. Peternak anggota Koperasi UPP Kaliurang memiliki lahan berupa pekarangan, digunakan untuk menanam hijauan berupa rumput Gajah, Kolonjono, dan tanaman perkebunan. Tabel
3 menunjukkan bahwa luas hijauan rata-rata $8.298,75 \mathrm{~m}^{2} /$ peternak, berarti kebutuhan hijauan pada musim penghujan dapat tercukupi dari lahan sendiri dan sewa lahan, sehingga tidak diperlukan untuk membeli. Pada musim kemarau peternak mengalami kesulitan untuk memenuhi pakan hijauan, dan terpaksa membeli berupa tebon atau membeli jerami.

\section{Faktor-faktor yang berpengaruh pada produksi susu sapi perah rakyat}

Hasil analisis regresi faktor-faktor yang berpengaruh pada produksi susu sapi perah rakyat dengan model Cobb-Douglas seperti Tabel 4. Berdasarkan Tabel 4, koefisien $\mathrm{R}^{2}$ sebesar 0,78 berarti bahwa $78,55 \%$ produksi susu dapat dijelaskan oleh faktor produksi $\mathrm{X}_{1}, \mathrm{X}_{2}, \mathrm{X}_{3}, \mathrm{X}_{4}, \mathrm{X}_{5}$, dan $\mathrm{X}_{6}$, dan sisanya yaitu $21,45 \%$ dijelaskan oleh variabel lain yang tidak masuk dalam model penelitian ini.

Untuk menguji pengaruh input atau faktor produksi secara bersama-sama terhadap produksi susu yang dihasilkan oleh peternak digunakan uji $\mathrm{F}$. Hasil $F$ hitung menunjukkan bahwa variable $X_{1}, X_{2}$, $\mathrm{X}_{3}, \mathrm{X}_{4}, \mathrm{X}_{5}$, dan $\mathrm{X}_{6}$ secara bersama-sama berpengaruh signifikan terhadap produksi susu $(\mathrm{P}<0,01)$.

\section{Efisiensi penggunaan sarana produksi}

Hasil analisis Cobb-Douglas dalam penelitian ini sebagai berikut :

$\operatorname{Ln} \mathrm{Y}=0,998+0,101 \ln \mathrm{X} 1-0,028 \ln \mathrm{X} 2+0,058$ $\ln \mathrm{X} 3-0,590 \ln \mathrm{X} 4+0,877 \ln \mathrm{X} 5+0,620 \ln \mathrm{X} 6$ Bentuk fungsi produksi Cobb-Douglas $\mathrm{Y}=2.726474 \mathrm{X} 1^{0,101} \mathrm{X} 2^{0,028} \mathrm{X} 3^{0,058} \mathrm{X} 4^{-0,590} \mathrm{X} 5$ ${ }^{0,877} \mathrm{X} 6^{0,620}$

Sesuai dengan Gujarati (2003), yang menyatakan bahwa penjumlahan koefisien regresi merupakan elastisitas produksi.

Elastisitas $b_{1}+b_{2}+b_{3}+\ldots+b_{6}=1,038$, lebih dari 1 , artinya produksi sapi perah dalam penelitian berada pada kondisi increasing return to scale (kenaikan hasil yang semakin bertambah). Pada 
Tabel 3. Rata-rata penggunaan sarana produksi pada responden anggota Koperasi UPP Kaliurang (averages production factors used in UPP Kaliurang Cooperative members)

\begin{tabular}{lrc}
\hline \hline \multicolumn{1}{c}{ Uraian (variables) } & $\begin{array}{r}\text { Rata-rata } \\
\text { (averages) }\end{array}$ & $\begin{array}{c}\text { Kisaran } \\
\text { (range })\end{array}$ \\
\hline Pakan hijauan yang diberikan $(\mathrm{kg} / \mathrm{hr} /$ responden) $($ forage given $(\mathrm{kg} /$ day/respondent)) & 164,60 & $40-460$ \\
Pakan hijauan yang diberikan $(\mathrm{kg} / \mathrm{hr} / \mathrm{UT})($ forage given $(\mathrm{kg} /$ day/AT) & 42,90 & $28,85-62,50$ \\
Pakan konsentrat yang diberikan $(\mathrm{kg} / \mathrm{hr})($ concentrate given $(\mathrm{kg} /$ day $))$ & 25,90 & $7-86$ \\
Pakan konsentrat yang diberikan $(\mathrm{kg} / \mathrm{hr} / \mathrm{UT})($ concentrate given $(\mathrm{kg} /$ day/AT)) & 6,50 & $4,57-8,85$ \\
Luas hijauan $\left(\mathrm{m}^{2}\right)\left(\right.$ land $\left.\left(\mathrm{m}^{2}\right)\right)$ & $8.298,70$ & $500-33,000$ \\
Tenaga kerja $(\mathrm{HOK})($ labor) & 1,51 & $0,44-3$ \\
\hline
\end{tabular}

Tabel 4. Hasil analisis regresi faktor-faktor yang berpengaruh terhadap produksi susu sapi perah rakyat dengan model fungsi produksi Cobb-Douglass (Ln) (results analysis of regression factors influenced to milk production of dairy cattle with production function model Cobb-Douglass (Ln))

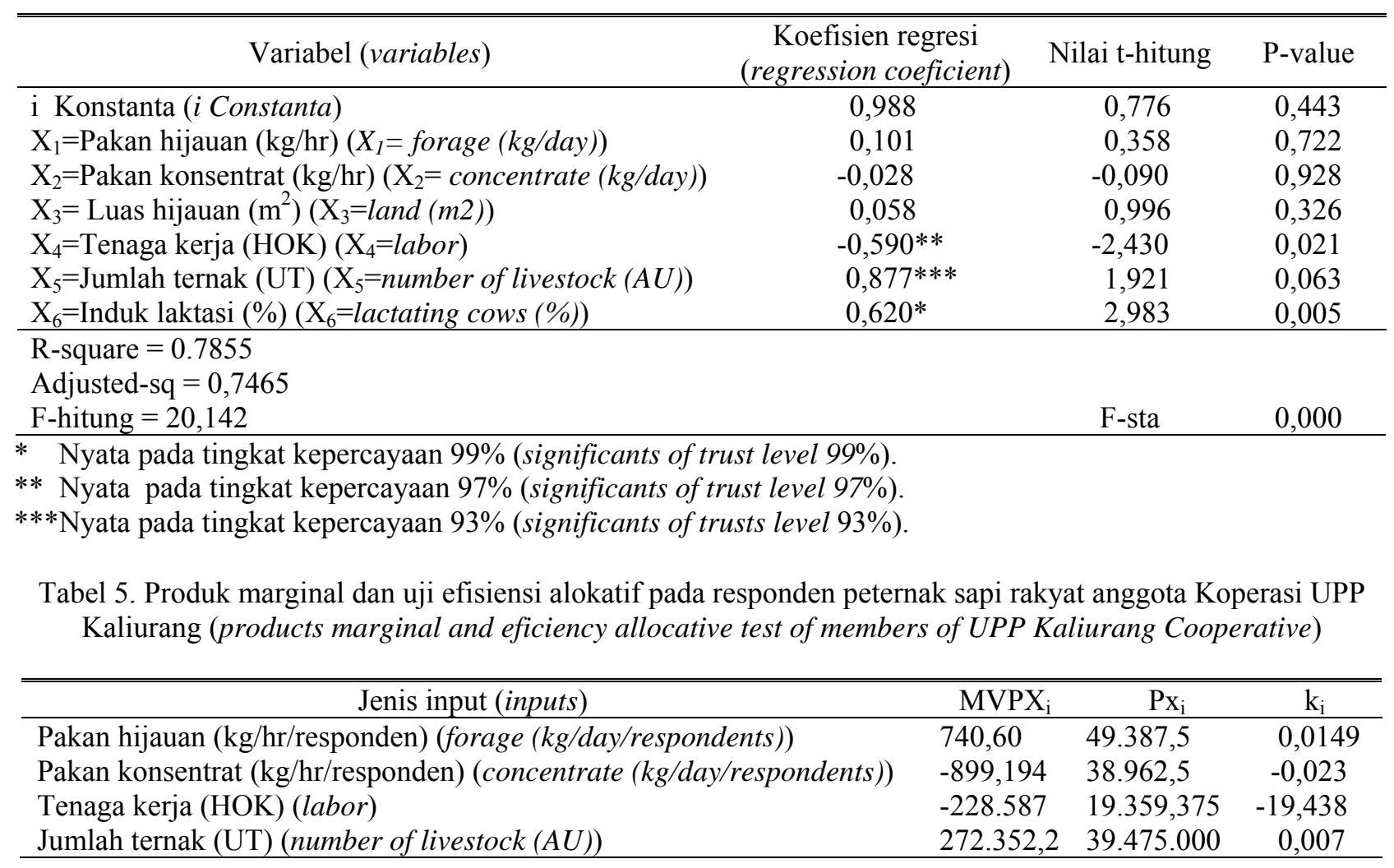

daerah ini keuntungan masih dapat ditingkatkan dengan meningkatkan jumlah input. Hasil penelitian ini menunjukkan bahwa faktor produksi pakan konsentrat dan hijauan tidak menunjukkan pengaruh yang nyata yang bisa meningkatkan produksi susu hanya jumlah ternak dan persentase laktasi.

Menurut Soekartawi (1990), efisiensi adalah penggunaan input yang sekecil mungkin untuk mendapatkan produksi yang sebesar-besarnya. Situasi yang demikian ini akan terjadi apabila petani mam$\mathrm{pu}$ membuat upaya nilai produk marjinal input usahatani yang digunakan adalah sama dengan harga input (Px) tersebut atau NPMxi = Pxi atau $(\mathrm{NPMxi} / \mathrm{Pxi})=1$.

Tabel 5 menunjukkan semua faktor produksi memiliki nilai $\mathrm{ki}<1$, berarti penggunaan faktor produksi pada peternak sapi perah rakyat tidak efisien.
Dalam analisis regresi pada faktor produksi jumlah ternak menunjukkan pengaruh signifikan, tetapi tidak efisien dalam efisiensi alokatif/harga. Jumlah ternak yang memberikan keuntungan maksimum untuk memproduksi susu tanpa produksi dari pedet dan kotoran ternak (pupuk), bila peternak memelihara sapi perah sebanyak 37 UT.

\section{Kesimpulan dan Saran}

\section{Kesimpulan}

Hasil analisis menunjukkan bahwa pakan hijauan, konsentrat, luas pemilikan lahan hijauan, tenaga kerja, jumlah ternak dan jumlah induk laktasi secara bersama-sama berpengaruh signifikan terhadap produksi susu dengan $\mathrm{R}^{2}=0,78$. Secara parsial persentase induk laktasi dan jumlah ternak 
berpengaruh signifikan positif terhadap produksi susu per peternak, namun jumlah pakan hijauan dan konsentrat tidak berpengaruh signifikan. Hal ini didukung hasil uji efisiensi alokatif menunjukkan bahwa pakan hijauan dan konsentrat belum mencapai efisiensi alokatif.

Secara teknis penggunaan faktor produksi belum rasional ditunjukkan dengan elastisitas produksi $($ Ep) $>1$ (1,462). Untuk menghasilkan keuntungan maksimum dengan produksi susu, maka jumlah ternak yang dipelihara 37 UT. Produksi susu rata-rata/induk laktasi/hari adalah 8,99 1, calving interval (CI) sekitar 15 bulan, dan persentase induk laktasi terhadap jumlah sapi perah $63 \%$.

\section{Saran}

Peternak rakyat disarankan untuk memperbaiki komposisi ternak non laktasi agar beban usaha ternak sapi laktasi tidak terlalu berat. Komposisi induk laktasi dan non laktasi sebaiknya sekitar $80 \%$ dari total ternak.

Penelitian untuk mengetahui efisiensi teknis dan alokatif terhadap produksi susu perlu dilakukan dengan unit analisis per induk laktasi dan dengan metode percobaan di tingkat peternak, dengan demikian bisa dihitung penggunaan faktor produksi yang optimal secara tepat di tingkat peternak.

\section{Daftar Pustaka}

Ditjen Peternakan. 2008. Buku Statistik Peternakan. Departemen Pertanian Republik Indonesia.
Gujarati, D. 2003. Ekonometrika Dasar. Erlangga. Jakarta.

Hadi, S. 2000. Statistik. Penerbit Andi. Yogyakarta.

Siregar, S.B. 2000. Aspek ekonomis suplementasi pakan konsentrat pada sapi perah laktasi. Media Peternakan 23(1).

Soekartawi. 1990. Teori Ekonomi Produksi dengan Pokok bahasan Analisis Fungsi CobbDouglas. CV Rajawali. Jakarta.

Soetarno, T. 2000. Ilmu Produksi Ternak Perah. Laboratorium Ternak Perah, Fakultas Peternakan Universitas Gadjah Mada. Yogyakarta.

Winarno. 1985. Analisa manajemen dan pemasaran susu usaha peternakan sapi perah rakyat dan perusahaan sapi perah di Kotamadya Yogyakarta. Tesis. Fakultas Peternakan. Universitas Gadjah Mada. Yogyakarta.

Yotopoulus, P.A. and Jeffrey b. Nugent. 1976. Economics of Development Emperical Investigations. Harper International Edition. New York.

Yusdja, Y. 2005. Kebijakan ekonomi agribisnis sapi perah di Indonesia. Analisis Kebijakan Pertanian. Volume 3 no 3. Pusat Analisis dan Kebijakan Pertanian, Bogor.

Zakaria, Y. 1989. Efisiensi usaha sapi perah rakyat di Kecamatan Pacet, Kabupaten Mojokerto, Jawa Timur. Tesis. Universitas Gadjah Mada, Yogyakarta. 